\title{
Response of hyporheic biofilm metabolism and community structure to nitrogen amendments
}

\author{
Stuart Findlay ${ }^{1, *}$, Robert L. Sinsabaugh ${ }^{2}$ \\ ${ }^{1}$ Institute of Ecosystem Studies, Millbrook, New York 12545, USA \\ ${ }^{2}$ Department of Biology, University of New Mexico, Box AB, Albuquerque, New Mexico 87131, USA
}

\begin{abstract}
Biofilms growing on gravel surfaces representative of hyporheic sediments were exposed to inorganic nitrogen or amino acid additions in experimental systems to examine potential responses in bacterial growth, oxygen removal, extracellular enzyme activities and bacterial community structure. Additions of ammonium and a mixture of amino acids increased oxygen removal by $>50 \%$ in small perfusion cores, with a stronger response to amino acids than equimolar $\mathrm{NH}_{4}$ addition. Some extracellular enzyme activities were affected by a significant increase in $\alpha$ - and $\beta$-glucosidase activities in amino acid relative to $\mathrm{NH}_{4}$ additions, while peptidase activities were only weakly affected by either $\mathrm{NH}_{4}$ or amino acid addition. Community structure assayed via RAPDs did not change in parallel with responses of metabolic variables, and there was no concordance between RAPD clusters and experimental treatment. In flow-through mesocosms mimicking hyporheic flowpaths, similar additions of $\mathrm{NH}_{4}$ and amino acids yielded significant differences in patterns of oxygen decline along the flowpaths. Differences in bacterial growth and extracellular enzyme activity were restricted to the sampling locations closest to the head of the flowpath (point of $\mathrm{N}$ injection) with a general convergence of values nearer the end of mesocosms. As for the perfusion core experiment, there was no concordance between metabolic and community structural response as measured by clustering of RAPD data. Nitrogen supply clearly altered biofilm metabolic activity but there was no parallel change in community structure. We suggest that the ability to acquire inorganic nitrogen or amino acid nitrogen is sufficiently distributed across bacterial taxa so that shifts in function do not necessarily require shifts in bacterial community structure.
\end{abstract}

KEY WORDS: Hyporheic $\cdot$ Metabolism $\cdot$ Dissolved inorganic nitrogen $\cdot$ Amino acids $\cdot$ Bacteria $\cdot$ Production $\cdot$ Respiration $\cdot$ Nitrification $\cdot$ Enzymes

\section{INTRODUCTION}

Bacteria in surface biofilms in running water ecosystems are responsible for a significant fraction of ecosystem respiration and carbon degradation (Grimm \& Fisher 1984, Naegeli \& Uehlinger 1997, Fischer et al. 2002). Small streams are also important sites of nitrogen removal from surface waters (Alexander et al. 2000, Peterson et al. 2001) and heterotrophic biomass or metabolism may be limited by availability of inorganic nutrients (Tank \& Webster 1998). Bacteria inhabiting inorganic surfaces are at least partially reliant on organic material and inorganic nutrients supplied by surrounding water, and such biofilms show shifts in metabolic activity with variation in the nature or quantity of solutes in transport (Findlay et al. 2003). Hyporheic sediments, those hydrologically connected to surface waters but existing in the dark, are reliant on dissolved organic matter (DOM) downwelling from surface waters, or supply of particulate organic matter, for energy (Findlay \& Sobczak 2000).

In many aquatic ecosystems, organic matter inputs are enriched in carbon relative to nitrogen and phosphorus. Terrestrial leaf litter has C:N ratios up to 10fold higher than the Redfield ratio (Enriquez et al. 1993). DOM leaving terrestrial ecosystems can have a C:N ratio from 10 to 20 (Seitzinger et al. 2002, Aitkenhead et al. 2003), suggesting microbes assimilating this 
material will face a shortage of $\mathrm{N}$ and $\mathrm{P}$ relative to carbon. Assimilation of inorganic $\mathrm{N}$ by heterotrophs can be a significant sink for inorganic nitrogen in many systems, and can be predicted from growth efficiencies, consumer $\mathrm{C}: \mathrm{N}$ ratios and the importance of allochthonous carbon inputs (Caraco \& Cole 2003). The form of nitrogen may well influence microbial activities since nitrate, the predominant form of inorganic nitrogen in most surface waters, requires reduction prior to incorporation into cellular components. In comparison, amino acids can be readily used as a source of nitrogen, energy or building blocks, and so may have multiple effects on bacterial metabolism (Kirchman 1994, Kirchman 2003). Aside from effects on metabolism, differences in nitrogen supply have been proposed as factors influencing the composition of bacterial communities. Taxa identified with probes specific to the Cytophaga-Flavobacteria group were particularly important in protein degradation, while amino acid uptake had a greater representation from the $\alpha$-proteobacteria group in samples from coastal waters (Cottrell \& Kirchman 2000).

Previously we have documented the removal of dissolved organic carbon along hyporheic flowpaths and significant differences among streams in rates of removal (Sobczak \& Findlay 2002). Several measures of bacterial metabolism showed significant variation in responses to shifts in carbon supply, and these metabolic responses were paralleled by shifts in bacterial community structure (Findlay et al. 2003). Because nitrogen may be an important regulator of bacterial metabolism and community structure, we examined the effect of ammonium and amino acids on model epilithic biofilms intended to mimic heterotrophic biofilms in hyporheic sediments. We used ammonium to represent a directly available inorganic form of nitrogen and amino acids, since these are among the most readily available $\mathrm{N}$-containing organic molecules, and therefore might have particularly strong effects on biofilm bacteria. In this study we examined the response of oxygen consumption to these nitrogen manipulations, bacterial production and activities of a suite of extracellular enzymes. In parallel we assessed potential shifts in bacterial community structure using RAPD analysis.

\section{MATERIALS AND METHODS}

Small cores (25 cm long, $5 \mathrm{~cm}$ diameter) containing low-organic content, commercially available gravel $(\sim 0.5 \mathrm{~cm})$ were gravity-fed with water (flow-rate adjusted daily to $10 \mathrm{~cm} \mathrm{~h}^{-1}$ ) collected from a local spring for 2 wk to allow colonization and establishment of biofilms prior to manipulation. Replicate cores (4 per treatment) were amended with either $\mathrm{NH}_{4} \mathrm{Cl}(30 \mu \mathrm{M})$ or an equimolar mixture of amino acids ( $7.5 \mu \mathrm{M}$ N each from glycine, aspartate, alanine, lysine), totaling $30 \mu \mathrm{M}$ N. Rates of oxygen removal in the cores were monitored by measuring dissolved oxygen in influent versus effluent water. Removal was calculated as:

$$
\begin{gathered}
\text { [effluent - influent } \left.\left(\mathrm{mg} \mathrm{l}^{-1}\right)\right] \times \text { flow }\left(\mathrm{l} \mathrm{h}^{-1}\right) / \\
\text { dry mass of gravel in the core }
\end{gathered}
$$

Influent $\mathrm{O}_{2}$ concentrations were measured with a YSI Model 57 DO Meter in head tanks feeding the cores, effluent concentrations were measured with the probe immersed in a small plastic cup that had been sealed and flushed with effluent water for $\sim 30 \mathrm{~min}$ before measurement. After $3 \mathrm{wk}$ of experimental treatment, cores were destructively sampled and sediments analyzed for rates of bacterial production and the activity of a suite of 8 extracellular enzymes. Bacterial production was estimated from the rate of incorporation of ${ }^{3} \mathrm{H}$-thymidine $\left({ }^{3} \mathrm{H}\right.$-TdR) into DNA following Findlay (1993). Briefly, $10 \mathrm{~g}$ of gravel was incubated with $5 \mathrm{ml}$ of water from the appropriate treatment for $1 \mathrm{~h}$ with $20 \mu \mathrm{Ci}$ of $20 \mathrm{Ci}$ mmole ${ }^{3} \mathrm{H}-\mathrm{TdR}^{-1}$ with incubation terminated by addition of $1 \mathrm{ml} 5 \%$ formaldehyde. There were 2 zero-time controls for each treatment, with formaldehyde added immediately after the thymidine. Radioactivity in controls was $<5 \%$ of live samples, and the mean value for controls was subtracted from all other values. Samples were washed $3 \times$ with $2 \%$ formaldehyde then frozen. DNA was extracted overnight under alkaline conditions, precipitated and washed in cold 5\% TCA prior to hydrolysis and scintillation counting.

Extracellular enzymes were assayed on biofilm suspensions obtained by vortexing $\sim 10 \mathrm{~g}$ of gravel for $2 \mathrm{~min}$. Aliquots measuring $150 \mu \mathrm{l}$ from the suspension were added to wells of microtiter plates, incubated in the dark on a shaker table, and fluorescence read at roughly hourly intervals. Rate of increase of fluorescence was used to calculate enzyme activity for the period of linear increase ( 2 to $3 \mathrm{~h}$ for the higher activity enzymes, as long as $18 \mathrm{~h}$ for the lower activities). Quenching and any pH effects on fluorescence detection were accounted for by adding small quantities of methylumbelliferone directly to the wells and calculating the fluorescence recovery relative to the same additions in buffer. Fluorochrome-linked substrates were used to measure potential activities of $\beta$-glucosidase ( $\beta \mathrm{GLU}), \quad \alpha$-glucosidase $(\alpha \mathrm{GLU}), \quad \mathrm{N}$ acetylglucosaminidase (NAG), $\beta$-xylosidase ( $\beta \mathrm{XYL})$, phosphatase (PHOS), leucine aminopeptidase (LEU), esterase (ACE) and endopeptidase (GUAN) following Findlay et al. (2001). All substrate concentrations were $400 \mu \mathrm{M}$, or at the limit of solubility if lower than this level. Two types of blanks (substrates plus water or 
water alone) were run with each set of assays to follow any changes in fluorescence not due to biofilm suspension. Change in substrate blank fluorescence was always less than 5 fluorescent units ( $0.5 \%$ of full scale), while change in fluorescence for biofilm samples was typically 50 to 500 fluorescent units.

Gravel samples reserved for DNA extraction were sealed in plastic bags and stored at $-80^{\circ} \mathrm{C}$. Community DNA was extracted using the MO-BIO Ultraclean Soil DNA Kit, following the macro protocol (MO-BIO Laboratories, see Rowher et al. 2001). Subsamples of extracted community DNA were used in polymerase chain reactions to generate RAPD, using reagents and protocol provided with the RAPD Analysis Primer Set kit (Amersham Pharmacia), (see Welsh \& McClelland 1990, Williams et al. 1990 for general description of RAPD analysis). The RAPD kit includes 6 arbitrary primers, each $10 \mathrm{bp}$ in length. Each primer was added to an aliquot of community DNA and subjected to PCR amplification. Each primer binds to inverted repeats within the community DNA, thereby amplifying intervening sequences of varying length. The resulting amplicons were separated by agarose gel electrophoresis and stained with ethidium bromide. The gels were scanned with a densitometer. Linear regressions, based on the Promega 100 bp DNA Ladder, were used to estimate fragment size. Fragments from the various samples were aligned, allowing for a $+5 \%$ error in size estimates. Because the primers differ in sequence, each produces a different distribution of amplicons. The size distribution of amplicons across the 6 primers represents a community 'signature'.

Gravel-filled pipes ( 3.5 m length, $15 \mathrm{~cm}$ diameter with 4 sampling wells) were used to mimic natural hyporheic flowpaths in local streams (Sobczak \& Findlay 2002). Springwater was gravity-fed from headtanks with control of flow (target $10 \mathrm{~cm} \mathrm{~h}^{-1}$, travel time $\sim 1.5 \mathrm{~d})$ by valves on the outlet hoses. A series of 4 standpipes at $0.3,1.3,2.3$ and $3.3 \mathrm{~m}$ from the head of the mesocosm were used to sample interstitial water at points along the flowpath, allowing for placement and incubation of small bags containing the same gravel used in the core experiment and filling the rest of the mesocosm. For $3 \mathrm{wk}$, the mesocosms were fed with only spring water until declines in oxygen along the flowpath suggested an active biofilm community. Ammonium chloride or amino acids (same concentrations and mixtures as above) were injected from a drip bottle into the feeder hose below the head tanks just before it entered the head of the mesocosms. There were 3 mesocosms for each treatment: no addition, $+\mathrm{NH}_{4}$, and +amino acids. After 6 wk of $\mathrm{N}$ amendment, sediment bags were removed and subsamples assayed for bacterial production, enzyme activity and RAPDs as above.
Dissolved organic carbon was measured with a hightemperature, catalytic method on a Shimadzu 5050 TOC Analyzer. Dissolved inorganic nitrate, ammonium and phosphate were measured with automated wet chemistry (Alpkem Flow Solution III).

All statistical analyses were done with Statistica (Statsoft) employing a 1-way ANOVA to test for treatment effects in perfusion cores and a 2-way ANOVA to examine effects of treatment and flowpath location in mesocosms. Principal components analysis (PCA) was used to simplify the 8 enzyme activities into new linear variables (usually 2) that encompassed the variability of the original data. PCA uses the correlation among variables rather than absolute rates so all variables have equal weight in the analysis. Similarity of community structure among treatments was assessed by cluster analysis of RAPD data (presence/absence only) (Ward's method, Euclidean distance).

\section{RESULTS}

Addition of nitrogen to perfusion cores significantly increased oxygen removal $\left(F_{2,9}=4.8 ; \mathrm{p}=0.04\right)$ but not production $\left(F_{2,9}=2.9 ; \mathrm{p}=0.11\right)$ (Fig. 1$)$. The amino acid addition caused the largest shift: oxygen removal was $50 \%$ higher than that of unamended controls. Several extracellular enzyme activities were affected by nitrogen amendments with almost 2-fold increases for both $\alpha$ - and $\beta$ GLU activity (ANOVA, $F_{2,9}=5.2, \mathrm{p}=0.03$ and $F_{2,9}=10.3, \mathrm{p}=0.005$, respectively) and weaker responses, $<50 \%$ in $\beta$ XYL $\left(F_{2,9}=3.4, \mathrm{p}=0.08\right)$ and LEU $\left(F_{2,9}=3.1, \mathrm{p}=0.095\right)$. PCA reduced the extracellular enzyme activity (EEA) data to 2 factors that accounted for 57 and $17 \%$ of the total variance (Fig. 2). The +amino acid treatment was displaced on PC1 relative to

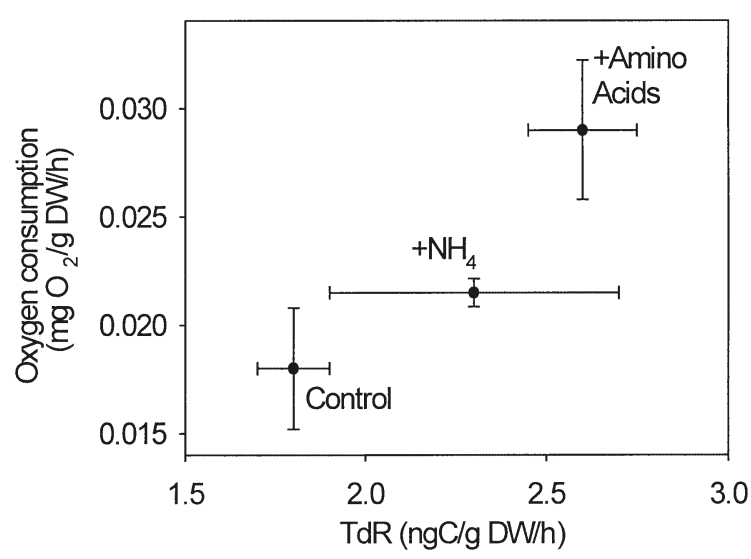

Fig. 1. Thymidine incorporation and oxygen consumption, measured in core perfusions. Values are means of 4 cores ( \pm 1 SE). DW: dry weight 


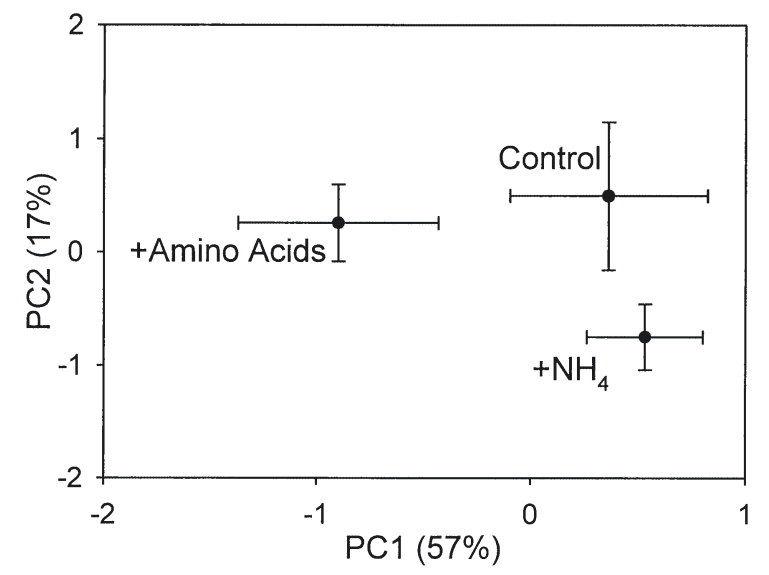

Fig. 2. Principal components analyses (PC1 and PC2) of 8 extracellular enzyme activities measured in the core perfusion experiment. The first 2 PCAs accounted for $71 \%$ of the total variance. Values shown are the mean score $( \pm 1 \mathrm{SE})$ for each treatment

unamended or ammonium-amended cores (ANOVA, $p=0.07$ ). Four enzymes ( $\alpha$ - and $\beta G L U, N A G$ and LEU) load negatively on PC1 (data not shown) so high rates for those enzymes in amino-acid amended samples would lead to a leftward shift in relative position on $\mathrm{PC} 1$. This represents an increase in 2 of the 3 carbohydrases (except XYL), an enzyme targeting an aminosugar and exo-peptidase activity.

Mesocosms receiving either ammonium or amino acids showed more rapid declines in dissolved oxygen along flowpaths than unamended mesocosms (ANOVA, Treatment $F_{2,30}=9.2, \mathrm{p}=0.001$; Well $F_{4,30}=$ 65.2 , p $<0.00001$; Fig. 4). Rates of oxygen removal estimated from an exponential model of dissolved oxygen, where $x$ is distance below headtank in $\mathrm{m}\left(\mathrm{DO}_{x}=\mathrm{DO}_{0} \times\right.$ $\mathrm{e}^{-k x}$ ) were $-0.24 \mathrm{~m}^{-1}$ for the control mesocosms and -0.58 and $-0.59 \mathrm{~m}^{-1}$ for the $+\mathrm{NH}_{4}$ and +amino acid

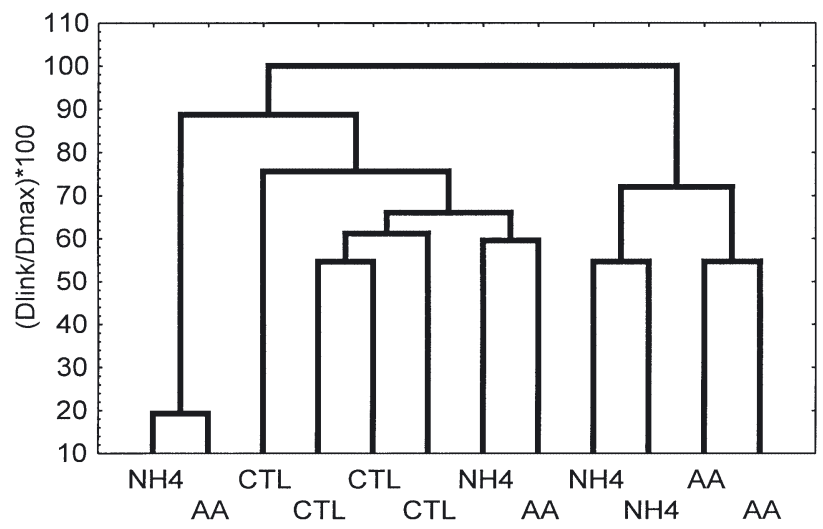

Fig. 3. Cluster diagram showing associations derived from RAPD analysis of samples from the core perfusions. CTL: control cores; AA: amino acid addition cores. Each sample represents an individual core mesocosms, respectively. Dissolved organic carbon concentrations showed small and non-significant $(\mathrm{p}=$ 0.23) declines along all mesocosm flowpaths with no significant difference $(p=0.18)$ among treatments (data not shown). Even DOC concentrations in the first well below amendment injection did not differ significantly among treatments $(\mathrm{p}=0.37)$.

For each sample the RAPD data consisted of 10 to 60 bands ranging in size from 200 to 2200 bp. Cluster analyses of these patterns based on presence/absence of bands showed no concordance between nitrogen treatments and clusters. Cores from each treatment were distributed among all cluster groups (Fig. 3) indicating that treatment was not a forcing factor for community composition.

Nitrogen amendments significantly increased overall nitrate concentrations $\left(F_{2,30}=18.0, \mathrm{p}=0.0001\right)$ in both $\mathrm{N}$-amended treatments, particularly at mid-points along the flowpath (Fig. 5A). Ammonium was at or

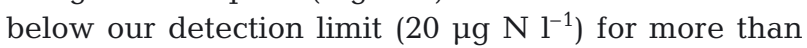
half the samples collected at the end of the experiment, despite our addition of $\sim 400 \mu \mathrm{g} \mathrm{N} \mathrm{I}^{-1}$ to amended mesocosms. Phosphate concentrations showed increases along flowpaths in all treatments with significant effects of flowpath position $\left(F_{4,29}=4.0, \mathrm{p}=0.01\right)$ but no effect of treatment $\left(F_{2,29}=1.28, \mathrm{p}=0.29\right)$ (Fig. 5B). In contrast to treatment effects on oxygen removal and nutrient concentrations, bacterial production on gravel incubated at locations along the flowpaths showed no difference among treatments $\left(F_{2,22}=0.71, \mathrm{p}=0.5\right)$ or well location $\left(F_{3,22}=0.34, \mathrm{p}=0.8\right)$ (Fig. 6). The overall range in production was small with even the maximum difference among treatment means in the first well below amendment injection (Well 1) only ca. $50 \%$ of the grand mean (zero addition mean $=0.78 \mathrm{ng} \mathrm{C} \mathrm{g}$ $\mathrm{DW}^{-1} \mathrm{~h}^{-1}[0.32 \mathrm{SD}]_{i}+\mathrm{NH}_{4}=1.05[0.47]_{i}+$ amino acids $=$ $1.24[0.26])$.

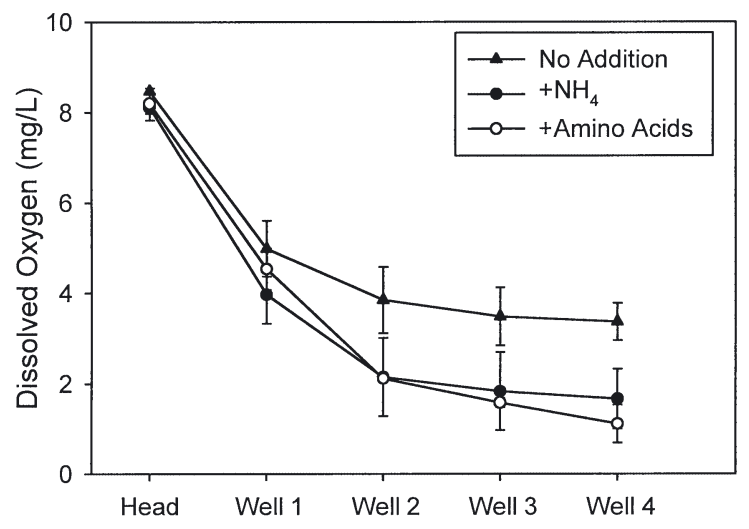

Fig. 4. Dissolved oxygen concentrations in head tanks and Wells 1 to 4 along the flowpath in experimental mesocosms. Values are means $( \pm 1 \mathrm{SE})$ 

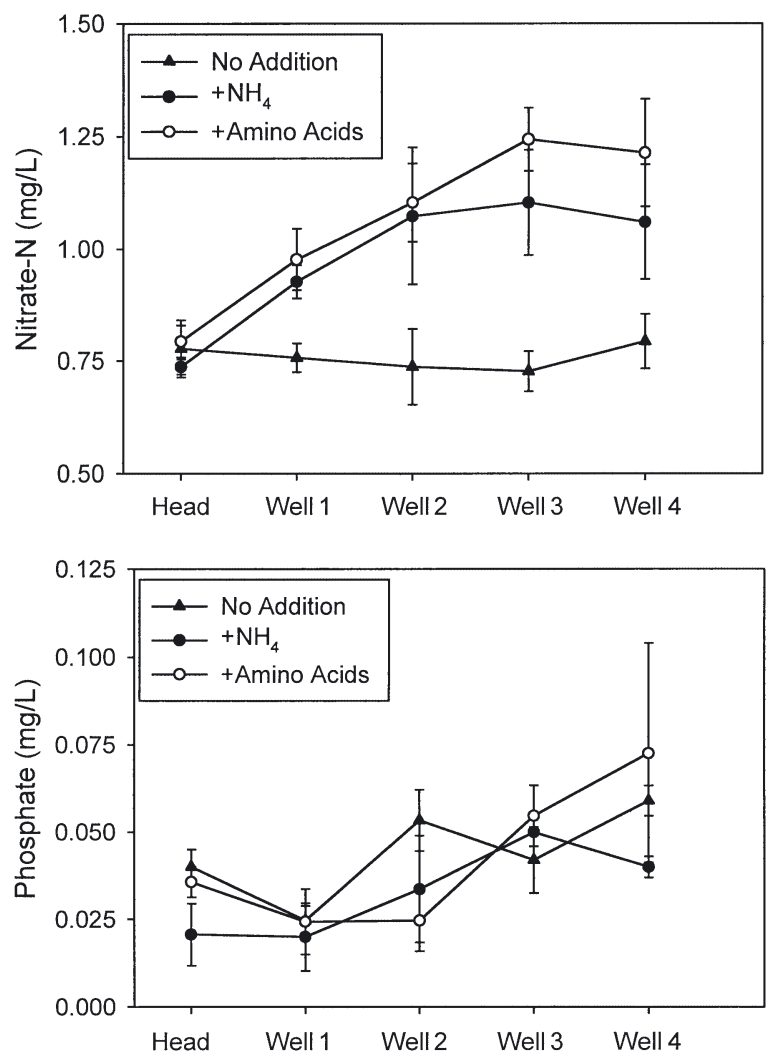

Fig. 5. Concentrations of (A) nitrate and (B) phosphate in water samples collected the same day gravel samples were removed. Values are means from 3 mesocosms $( \pm 1 \mathrm{SE})$

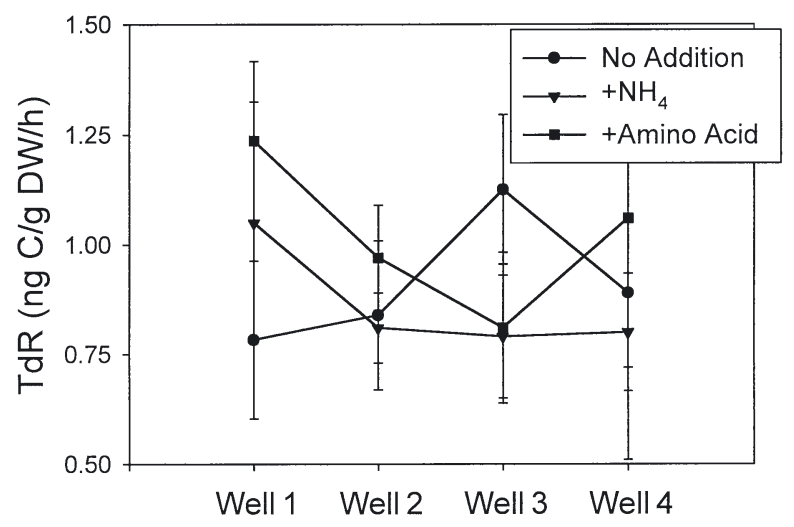

Fig. 6. Rates of bacterial production (thymidine [TdR] incorporation) in mesocosms receiving different nitrogen manipulations. Values are means across 3 mesocosms ( $\pm 1 \mathrm{SE})$

Nitrogen amendment to mesocosms affected only 2 of the 8 extracellular enzyme activities. Phosphatase activity was higher at the head of flowpath in Namendments, declining to values similar to controls at sampling locations closer to the end of the flow-
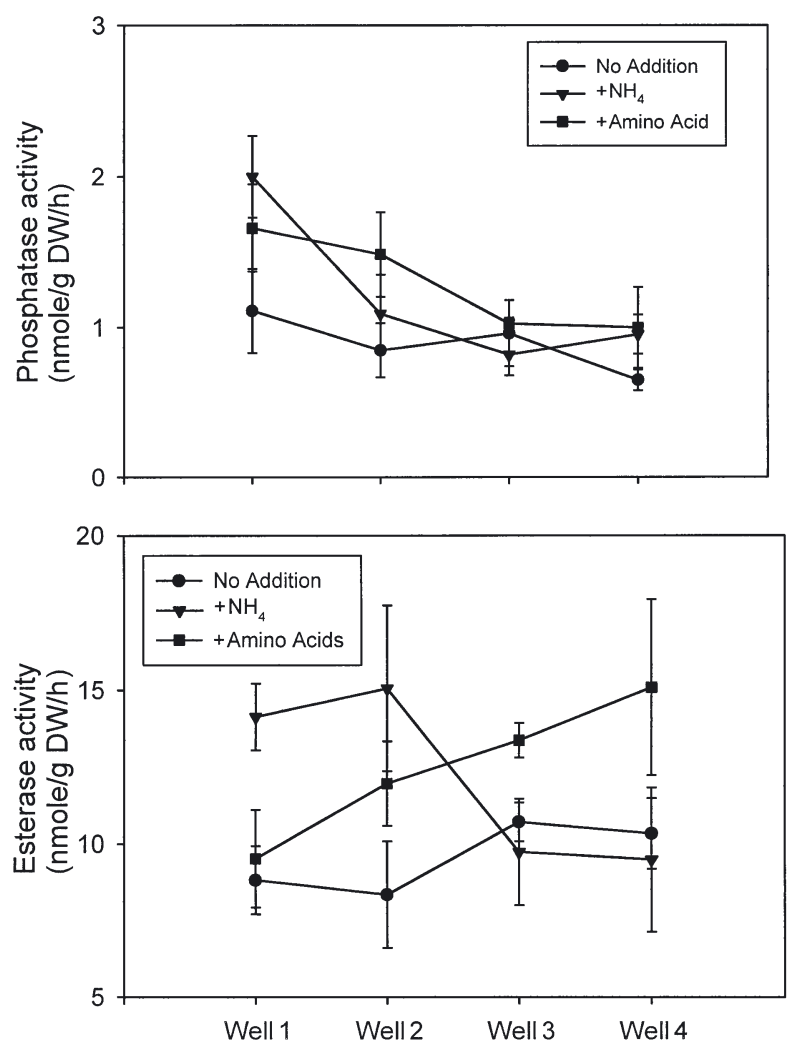

Fig. 7. Activities of (A) phosphatase and (B) esterase at well locations in mesocosms. Values are means of 3 mesocosms ( \pm 1 SE). DW: dry weight

path (Fig. 7A). Phosphatase activity was negatively correlated with phosphate concentration $(\mathrm{p}<0.05$, $\mathrm{r}=-0.61)$. Esterase activity differed significantly (2-way ANOVA: Treatment $F_{2,22}=3.54, \mathrm{p}=0.05$; Well $F=0.2 \mathrm{p}=0.9$ ) among treatments, with higher activities in $\mathrm{N}$-amended mesocosms (Fig. 7B). Highest activities occurred at different flowpath locations in different treatments, but esterase activity was not correlated with any of the inorganic nutrients, dissolved organic carbon or oxygen. Leucine aminopeptidase differed among treatments when the analysis was restricted to Well 1, the location immediately below the injection point for $\mathrm{N}$ amendments $\left(F_{2,5}=6.2 ; \mathrm{p}=0.05\right)$. Rates of LEU activity in Well 1 of the +ammonium mesocosms were approximately twice that of both other treatments, but values were indistinguishable at other well locations (data not shown).

As with the microcosm experiments, cluster analysis of RAPD data showed that variation in community composition was not correlated with treatment or flowpath location (Fig. 8). Samples from different treatment/location combinations were intermingled. 


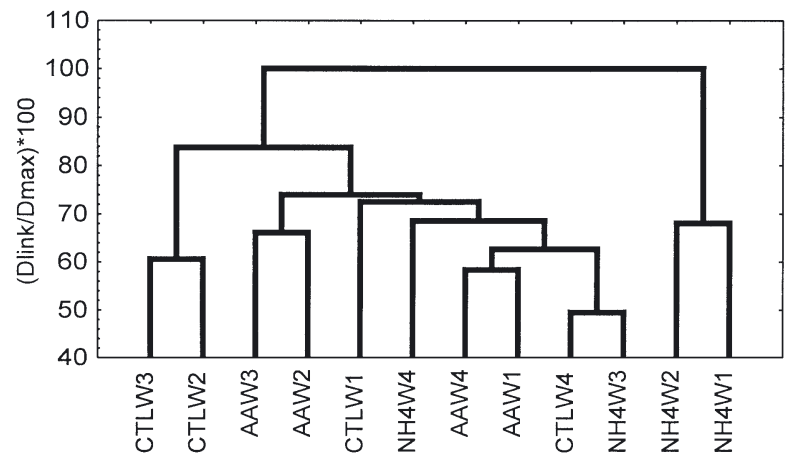

Fig. 8. Cluster analysis of RAPD data from mesocosms experiments. Samples are identified by treatment and Well \# (W1 is head of flowpath, W4 is tail). Dlink, Dmax: linking distance for a particular sample and maximal distance. Abbreviations as in Fig. 3

\section{DISCUSSION}

Microbial biofilm communities on inorganic surfaces are sensitive to differences in surrounding water chemistry as well as susceptible to physical disturbance (Battin et al. 2001, Fischer 2003). Manipulation of nitrogen availability had strong effects on biofilm oxygen removal in both our small and meso-scale experiments, but had no statistically significant effect on bacterial growth in either case. Addition of either ammonium or amino acids caused substantial regeneration of nitrate- $\mathrm{N}$ along mesocosm flowpaths. The increases in $\mathrm{NO}_{3}-\mathrm{N}$ observed between the source water (pre-N injection) and the peak $\mathrm{NO}_{3}-\mathrm{N}$ concentration observed along the flowpath (Fig. 5A) were 18 and $21 \mu \mathrm{M} \mathrm{N}$ in the $\mathrm{NH}_{4}$ and amino-acid amended mesocosms respectively. These amounts represent 60 and $70 \%$ of added $\mathrm{N}$ in these treatments, suggesting efficient nitrification (rather than immobilization) of added nitrogen along these flowpaths, where travel time is ca. $1 \mathrm{~d}$. The fact that rates of oxygen removal and $\mathrm{NO}_{3}$ accumulation were the same for both the $+\mathrm{NH}_{4}$ and +amino acid treatments suggests the mineralization of amino acids to $\mathrm{NH}_{4}$ was rapid and nonlimiting. In the hyporheic zone of Sycamore Creek, a $\mathrm{N}$-limited desert stream, Jones et al. (1995) found rapid mineralization and nitrification at sites where downwelling stream water supplied algal derived organic matter to sub-surface sediments. Similarly, Bernhardt et al. (2002) report that nitrification in some streams of the Hubbard Brook Valley (White Mountains, New Hampshire, USA) is sufficient to alter bulk streamwater nitrate concentrations. In Eagle Creek, Michigan, Hamilton et al. (2001) determined that nitrification accounted for about half the ammonium uptake during a ${ }^{15} \mathrm{~N}$ tracer study. Kemp \& Dodds (2002) found that rates of nitrification in most stream biotic compart- ments responded very strongly to $\mathrm{NH}_{4}$ addition in a suite of experiments. These findings, together with our results, suggest there is a population of nitrifiers in many stream sediments capable of processing a significant proportion of $\mathrm{N}$ inputs, thus altering the likelihood of $\mathrm{N}$ retention in a stream reach. If organic $\mathrm{N}$ or ammonium uptake is rapidly returned to the overlying water as nitrate, then retention of these compounds is short-term, and stream biota will have, at best, a transient effect on whole-system nitrogen transport.

Differences in dissolved-oxygen declines observed in control versus $+\mathrm{N}$ mesocosms may be accounted for, in part, by nitrifier oxygen demand. The net difference in $\mathrm{O}_{2}$ concentration is ca. $60 \mu \mathrm{M}$ (Fig. 4), while the net gains in $\mathrm{NO}_{3}$ in $+\mathrm{NH}_{4}$ and +amino acid treatments were 18 and $21 \mu \mathrm{M}$ respectively, suggesting that net nitrification could have consumed about half the dissolved oxygen removed along the mesocosm flowpath. $\mathrm{N}$ amendments in our mesocosms have apparently stimulated the metabolic activity of certain populations of nitrifiers rather than having large, broadly distributed effects on heterotrophs.

Phosphorous cycling was also influenced by $\mathrm{N}$ manipulation, with significantly higher activity of phosphatase near the head of $\mathrm{N}$-amended mesocosm flowpaths. The high ambient dissolved inorganic nitrogen (DIN): $\mathrm{PO}_{4}$ ratio ( $>100: 1$ molar ratio) of source water used in these experiments would imply fairly strong $\mathrm{P}$ limitation, and addition of available $\mathrm{N}$ may well have stimulated phosphatase activity for acquisition of $\mathrm{P}$ from organic sources. In all treatments there is the possibility that declining oxygen concentrations have released some $\mathrm{PO}_{4}$ via desorption along the mesocosm flowpaths (Fig. 5B). Phosphatase activity was significantly $(p<0.05)$ negatively $(r=-0.61)$ correlated with phosphate concentration in accordance with the general expectation that high inorganic P availability will repress phosphatase activity. In contrast to previously observed strong effects of carbon manipulations on hyporheic biofilm metabolism (e.g. Sobczak \& Findlay 2002, Findlay et al. 2003), we observed relatively small, often statistically insignificant changes in both bacterial growth and many of the extracellular enzyme activities following nitrogen manipulation. Natural variation in DOM can generate 2-fold differences in rates of bacterial growth and extracellular enzyme activities, and these functional shifts are often accompanied by demonstrable shifts in community structure, as measured by RAPD analysis (Findlay et al. 2003). Our $\mathrm{N}$ amendments led to significant increases in rates of oxygen removal in both microcosms and mesocosms, but only had minor effects on bacterial growth. Some nitrifiers are unable to incorporate exogenous thymidine (Johnstone \& Jones 1989), so any increased nitrifier growth may not be detected 
as an increase in thymidine incorporation. The fact that nitrifier $\mathrm{O}_{2}$-demand accounts for roughly half the increased oxygen removal in $\mathrm{N}$-amended mesocosms suggests some increase in heterotrophic activity following $\mathrm{N}$ addition. Bulk DOC removal did not differ among treatments, although the fact that the $\mathrm{C}$ added with amino acids did not appear as elevated DOC suggests there was extremely rapid, and therefore localized, removal of amino acid carbon. Much of this carbon must have remained in organic form (adsorbed or assimilated) since complete mineralization to $\mathrm{CO}_{2}$ would have caused an additional oxygen decline of $\sim 100 \mu \mathrm{M}$, assuming a RQ of 1. Fiebig (1997) also found rapid immobilization of amino acids with apparently long 'storage' before eventual mineralization to $\mathrm{CO}_{2}$. These results point to enhanced nitrification and associated oxygen removal as the major responses to $\mathrm{N}$ addition, with some increase in non-nitrifier respiration and amino acid turnover.

Thus, nitrogen amendment has altered fundamental aspects of nitrogen cycling in these experiments and would affect overall $\mathrm{N}$-retention by the biofilm community. Even over fairly short-term manipulations, conversion of $\mathrm{NH}_{4}$ or amino acids to nitrate will allow significant $\mathrm{N}$ loss from biofilms and export to downstream reaches. In a comparative study of ${ }^{15} \mathrm{~N}^{-\mathrm{NH}_{4}}$ uptake in streams, there was rapid removal of ${ }^{15} \mathrm{~N}^{-\mathrm{NH}_{4}}$ from all systems, with uptake lengths in smaller streams ranging from 10 to $60 \mathrm{~m}$ (Mulholland et al. 2002). If efficient nitrification is common across streams then rapid removal of $\mathrm{NH}_{4}$ or organic $\mathrm{N}$ from the water column cannot be equated with $\mathrm{N}$ retention over more than a few days time-span.

Nitrogen amendments did not have strong or consistent effects on most carbon-acquiring extracellular enzymes, suggesting there was neither an overall change in processing of polymeric organic carbon compounds nor a shift among components of DOM undergoing degradation. One might expect that supply of available nitrogen (either $\mathrm{NH}_{4}$ or amino acids) would allow substantial increases of biomass or production leading to a general increase in enzyme activities as carbon demand increases. As discussed above, there was some increase in heterotrophic oxygen consumption but this was not accompanied by higher growth rates measured by thymidine incorporation. Lack of changes in the activity of most enzymes and the bacterial growth rate suggest the $\mathrm{N}$ amendments were more important as modifiers of $\mathrm{N}$ transformation rather than as stimulators of heterotrophic metabolic activity. This finding has some parallels to results from forest soil systems, where $\mathrm{N}$ amendment tends to depress oxidative enzyme activities, increase glycosidase activities, increase DOC production, and promote sequestration of humus without large shifts in community composition (Carreiro et al. 2000, Neff et al. 2002, Saiya-Cork et al. 2002, Sinsabaugh et al. 2002, 2003). However, the microbial communities of forest soils include a large fungal component that was not present in our treatments, so it is not clear whether similar trends should be expected, but higher glycosidase activity with little change in community composition seems to be a common feature of both systems in the limited number of studies to date.

The apparent stimulation of chemolithotrophic nitrifiers rather than heterotrophs by $\mathrm{N}$ additions was somewhat surprising given previous documentation of strong links between heterotrophs and ammonia or amino acids (c.f. Tank \& Webster 1998, Kirchman 2003). Perhaps if there had been greater carbon availability in the spring water we used, or presence of substantial pools of particulate organic matter in the experimental sediments, there would be more $\mathrm{N}$ incorporated into heterotrophs and higher accumulation of biomass, thus allowing greater and longer term retention of N. In a study of nitrate uptake in a low DOC stream in the Catskill Mountains, New York State, Sobczak et al. (2003) showed that addition of a labile carbon source greatly enhanced the rates of nitrate removal and incorporation of nitrate- $\mathrm{N}$ into heterotrophic biomass. The increased bacterial production observed following labile DOC addition was sufficient to account for roughly $60 \%$ of the nitrate loss from solution. In the absence of labile DOC, nitrate was not removed from experimental hyporheic flowpaths and would simply be exported to downstream reaches. Similarly, Bernhardt \& Likens (2002) found that addition of acetate to a small, low-DOC stream caused increased nitrate uptake and a decrease in nitrification. In contrast to results suggesting organic matter stimulated heterotrophic immobilization, Ingendahl et al. (2002) found that hyporheic nitrification was higher downstream of a sewage treatment plant, which presumably supplies organic material, and rates were positively correlated with sediment particulate organic matter. In our mesocosms, DOC was low and did not decline significantly along flowpaths, suggesting low carbon availability and thus lessening the chance that heterotrophic microbes could act as a substantial sink for inorganic nitrogen.

In our experiments, we wanted to keep the unavoidable carbon amendment due to amino acid addition as small as possible, so we used amino acids with high $\mathrm{N}: \mathrm{C}$ ratios. The $\mathrm{C}$ added with amino acids was $1080 \mu \mathrm{g}$ $\mathrm{C}^{-1}$, which is roughly equal to ambient DOC. The fact that we did not observe an increase in DOC even in the well immediately below the $\mathrm{N}$ injection point, and nor did we observe an increased bacterial growth at that point, suggests extremely rapid removal of these compounds by sediments $(0.3 \mathrm{~m}$, roughly $3 \mathrm{~h}$ travel time) 
above our first sampling point. In Fiebig's (1997) core experiments, amino acid removal occurred $2 \mathrm{~cm}$ from the point of injection. In small streams, complete $\mathrm{NH}_{4}$ removal from the water column can occur in as short a distance as $25 \mathrm{~m}$, which is equivalent to a few minutes travel time (Mulholland et al. 2002). Given our mesocosm flow rates, this is equivalent to traveling through only a few $\mathrm{cm}$ of sediment, suggesting much of the initial uptake occurs above our first sampling point. The effect on oxygen concentration and appearance of elevated nitrate suggest rapid release followed by nitrification. Initial removal of both $\mathrm{NH}_{4}$ and amino acids from solution may be through abiotic adsorption, but the net transformation is to nitrate within a relatively short time period.

The lack of effect of $\mathrm{NH}_{4}$ or amino acids on enzymes targeting N-containing compounds (LEU, GUAN) was unexpected, since one might predict inhibition of peptidase activity by inorganic nitrogen addition or induction of peptidases by amino acids. Leucine aminopeptidase is among the most commonly assayed of enzyme activities in aquatic systems. Studies in planktonic systems have linked this activity to peptide availability and growth. Amendment studies suggest that community activity can be increased by adding dissolved proteins, but there was little down-regulation in response to additions of inorganic or monomeric $\mathrm{N}$ (Foreman et al. 1998). Other studies have observed stimulatory effects of natural dissolved organic nitrogen (DON) and inhibitory effects of nitrate on aminopeptidase activity (Stepanauskas et al. 1999). In a study of riparian DOM processing, aminopeptidase activity was positively correlated with amino acids and negatively correlated with nitrate in pastures, with no discernible relationships in forests (Findlay et al. 2001). These complex and idiosyncratic relationships between $\mathrm{N}$-acquiring enzyme activity and DON or DIN availability in diverse environments suggest multiple controls on these activities.

An important feature of enzymes targeting $\mathrm{N}$ containing compounds is the diversity of fates for the end-products. End-products may be a simple nitrogen source, a source of energy via catabolism of the amino acids, or use of intact amino acids as building blocks for protein synthesis. If, for instance, peptidases are acting primarily to generate amino acids to fuel cellular metabolism, then increasing availability of inorganic $\mathrm{N}$ should have little effect on peptidase activity. If, in contrast, peptidases are acting to generate nitrogen, then provision of inorganic nitrogen should depress peptidase activity. Given the high ambient DIN and low bulk DOC in source waters used in our experiment, it seems likely that peptidases were targeted at carbon aquisition to support metabolism, rather than acting simply to acquire nitrogen from organic sources, and so would not necessarily be inhibited by $\mathrm{NH}_{4}$ addition.

While nitrogen amendments have clearly altered some aspects of $\mathrm{N}$-processing in these experiments, there was not a parallel effect on community structure, suggesting these functional shifts were not accompanied by, and did not require, a reallocation among bacterial taxa. There are several potential reasons for this observed lack of correlation between microbial function and structure observed. Perhaps the simplest argument is that some factors capable of generating shifts in functions may not have had a strong effect on bacterial growth rates, thereby making it more difficult for taxa to change in relative abundance. In both our types of experiments oxygen removal increased, but this does not necessarily mean a change in actual cell division; it could be due to a decrease in growth efficiency or a shift towards nitrification. Nitrifiers are notoriously slow-growing, so perhaps even if they are capable of causing an increase in nitrification, they will not make up a substantial proportion of the bacterial community, and thus would not cause a detectable shift in community structure. In wastewater biofilms, ammonium-oxidizers and nitrite-oxidizers can be detected at high abundances by fluorescent in situ hybridization (e.g. Gieseke et al. 2001), but we do not know their abundance relative to heterotrophic bacteria under more natural conditions. Lastly, the RAPD analysis does not provide quantitative estimates of the size of any given population, and it is conceivable that some nitrifiers had increased in abundance but could not shift our similarity patterns based on presence/absence of bands.

Our experiments have documented significant effects of nitrogen additions on several aspects of bacterial metabolism in hyporheic biofilms. The rapid uptake of ammonia and amino acids and regeneration of $\mathrm{NO}_{3}$ is consistent with several field measurements and lab experiments, showing that nitrifiers are capable of altering net retention of nitrogen in stream sediments. Particularly where carbon availability is low, nitrifiers may 'intercept' mineralized $\mathrm{N}$ prior to incorporation or recycling into heterotrophic biomass. The net effect is a reduction in overall $\mathrm{N}$ retention in such streams. Since it appears that no shift among bacterial taxa accompanied these changes in nitrogen processing, it suggests that the requisite taxa are present and capable without requiring long times for populations to accumulate.

\section{LITERATURE CITED}

Aitkenhead JA, McDowell WH, Neff JC (2003) Sources, production, and regulation of allochthonous dissolved organic matter inputs to surface waters. In: Findlay SEG, 
Sinsabaugh RL (eds) Aquatic ecosystems - interactivity of dissolved organic matter. Academic Press, San Diego, CA, p 25-70

Alexander RB, Smith RA, Schwarz GE (2000) Effect of stream channel size on the delivery of nitrogen to the Gulf of Mexico. Nature 403:758-761

Battin T, Wille A, Sattler B, Psenner R (2001) Phylogenetic and functional heterogeneity of sediment biofilms along environmental gradients in a glacial stream. Appl Environ Microbiol 67:799-807

Bernhardt ES, Likens GE (2002) Dissolved organic carbon enrichment alters nitrogen dynamics in a forest stream. Ecology 83:1689-1700

Bernhardt ES, Hall RO, Likens GE (2002) Whole-system estimates of nitrification and uptake in streams of the Hubbard Brook Experimental Forest. Ecosystems 5: $419-430$

Caraco NF, Cole JJ (2003) The importance of organic nitrogen production in aquatic systems: a landscape perspective. In: Findlay SEG, Sinsabaugh RL (eds) Aquatic ecosystems - interactivity of dissolved organic matter. Academic Press, San Diego, CA, p 263-283

Carreiro MM, Sinsabaugh RL, Repert DA, Parkhurst DF (2000) Microbial enzyme shifts explain litter decay responses to simulated nitrogen deposition. Ecology 81: 2359-2365

Cottrell MT, Kirchman DL (2000) Natural assemblages of marine proteobacteria and members of the CytophagaFlavobacter cluster consuming low-and high-molecularweight dissolved organic matter. Appl Environ Microbiol 66:1692-1697

Enriquez S, Duarte CM, Sand-Jensen K (1993) Patterns in decomposition rates among photosynthetic organisms: the importance of detritus C:N:P content. Oecologia 94: $457-471$

Fiebig D (1997) Microbiological turnover of amino acids immobilized from groundwater discharged through hyporheic sediments. Limnol Oceanogr 42:763-768

Findlay S (1993) Thymidine incorporation into DNA as an estimate of sediment bacterial production. In: Kemp PF, Sherr EB, Cole JJ (eds) Handbook of methods in aquatic microbial ecology. Lewis Publishers, Boca Raton, FL, p 505-508

Findlay S, Sobczak WV (2000) Microbial communities in hyporheic sediments. In: Jones JB, Mulholland PJ (eds) Surface-subsurface interactions in streams. Academic Press, San Diego, CA, p 287-306

Findlay S, Quinn J, Hickey C, Burrell G, Downes M (2001) Land-use effects on supply and metabolism of stream dissolved organic carbon. Limnol Oceanogr 46:345-355

Findlay S, Sinsabaugh RL, Sobczak WV, Hoostal M (2003) Metabolic and structural response of hyporheic microbial communities to variations in supply of dissolved organic matter. Limnol Oceanogr 48:1608-1617

Fischer H (2003) The role of biofilms in the uptake and transformation of dissolved organic matter. In: Findlay S, Sinsabaugh RL (eds) Aquatic ecosystems: interactivity of dissolved organic matter. Academic Press, San Diego, CA, p 285-313

Fischer H, Wanner S, Pusch M (2002) Bacterial abundance and production in river sediments as related to the biochemical composition of particulate organic matter (POM). Biogeochemistry 61:37-55

Foreman CM, Franchini P, Sinsabaugh RL (1998) The trophic dynamics of riverine bacterioplankton: relationships among substrate availability, ectoenzyme kinetics, and growth. Limnol Oceanogr 43:1344-1352
Gieseke A, Purkhold U, Wagner M, Amann R, Schramm A (2001) Community structure and activity dynamics of nitrifying bacteria in a phosphate-removing biofilm. Appl Environ Microbiol 67:1351-1362

Grimm NB, Fisher SG (1984) Exchange between surface and interstitial water: implications for stream metabolism and nutrient cycling. Hydrobiologia 111:219-228

Hamilton SK, Tank JL, Raikow DF, Wollheim WM, Peterson BJ, Webster JR (2001) Nitrogen uptake and transformation in a Midwestern US stream: a stable isotope enrichment study. Biogeochemistry 54:297-340

Ingendahl $\mathrm{D}$, ter Haseborg $\mathrm{E}$, Meier $\mathrm{M}$, van der Most $\mathrm{O}$, Steele H, Werner D (2002) Linking hyporheic community respiration and inorganic nitrogen transformations in the River Lahn (Germany). Arch Hydrobiol 155:99-120

Johnstone BH, Jones RD (1989) A study on the lack of [Methyl $\left.-{ }^{3} \mathrm{H}\right]$ thymidine uptake and incorporation by chemolithotrophic bacteria. Microb Ecol 18:73-77

Jones JB, Fisher SG, Grimm NB (1995) Nitrification in the hyporheic zone of a desert stream ecosystem. J N Am Benthol Soc 14:249-258

Kemp MJ, Dodds WK (2002) The influence of ammonium, nitrate, and dissolved oxygen concentrations on uptake, nitrification, and denitrification rates associated with prairie stream substrata. Limnol Oceanogr 47(5): 1380-1393

Kirchman DL (1994) The uptake of inorganic nutrients by heterotrophic bacteria. Microb Ecol 28:255-271

Kirchman DL (2003) The contribution of monomers and other low-molecular weight compounds to the flux of dissolved organic material in aquatic ecosystems. In: Findlay SEG, Sinsabaugh RL (eds) Aquatic ecosystems - interactivity of dissolved organic matter. Academic Press, San Diego, CA, p 217-241

Mulholland PJ, Tank JL, Webster JR, Bowden WB and 12 others (2002) Can uptake length in streams be determined by nutrient addition experiments? Results from an interbiome comparison study. J N Am Benthol Soc 21:544-560

Naegeli MW, Uehlinger U (1997) Contribution of the hyporheic zone to ecosystem metabolism in a pre-alpine gravel-bed river. J N Am Benthol Soc 16:794-804

Neff JC, Townsend AR, Gleixner G, Lehman SJ, Turnball J, Bowman WD (2002) Variable effects of nitrogen additions on the stability and turnover of soil carbon. Nature 419: 915-917

Peterson BJ, Wollheim W, Mulholland PJ, Webster JR and 11 others (2001) Control of nitrogen export from watersheds by headwater streams. Science 292:86-90

Rohwer F, Breitbart M, Jara J, Azam F, Knowlton N (2001) Diversity of bacteria associated with the Caribbean coral Montastraea franksi. Coral Reefs 20:85-91

Saiya-Cork KR, Sinsabaugh RL, Zak DR (2002) Effects of long-term nitrogen deposition on extracellular enzyme activity in an Acer saccharum forest soil. Soil Biol Biochem 34:1309-1315

Seitzinger SP, Sanders RW, Styles R (2002) Bioavailability of DON from natural and anthropogenic sources to estuarine plankton. Limnol Oceanogr 47:353-366

Sinsabaugh RL, Carreiro MM, Repert DA (2002) Allocation of extracellular enzymatic activity in relation to litter composition, $\mathrm{N}$ deposition, and mass loss. Biogeochemistry 60: $1-24$

Sinsabaugh RL, Zak DR, Gallo M, Lauber C, Amonette R (2003) Nitrogen deposition and dissolved organic matter production in northern temperate forests. Soil Biol Biochem (in press)

Sobczak WV, Findlay S (2002) Variation in bioavailability of 
dissolved organic carbon among stream hyporheic flowpaths. Ecology 83:3194-3209

Sobczak WV, Findlay S, Dye S (2003) Relationships between DOC bioavailability and nitrate removal in an upland stream: an experimental approach. Biogeochemistry 62: 309-327

Stepanauskas R, Edling H, Tranvik LJ (1999) Differential dissolved organic nitrogen availability and bacterial aminopeptidase activity in limnic and marine waters. Microb Ecol 38:264-272

Editorial responsibility: Bess Ward,

Princeton, New Jersey, USA
Tank JL, Webster JR (1998) Interaction of substrate and nutrient availability on wood biofilm processes in streams. Ecology 79:2168-2179

Welsh J, McClelland M (1990) Fingerprinting genomes using PCR with arbitrary primers. Nucleic Acids Res 18: 7213-7218

Williams JGK, Kubelik AR, Livak KJ, Rafalski JA, Tingey SV (1990) DNA polymorphisms amplified by arbitrary primers are useful as genetic markers. Nucleic Acids Res 18: $6531-6535$

Submitted: May 20, 2003; Accepted: July 8, 2003

Proofs received from author(s): August 18, 2003 